\title{
R8: Restoration Aid to Africa
}

Last January, I traveled to Senegal in West Africa to attend the Bouki Blues Festival - an event that acknowledged and celebrated the gifts of music, dance, and culture that slaves from Senegal brought to the Americas. The festival, which I enjoyed with a group of Africans, Europeans and Americans, took place first at University Cheikh Anta Dop in Dakar and then in a small village along the Siné-Saloum Delta, near the town of Ndangane.

I'm not much of a traveler and had never been to Africa before, so to say I was unprepared for the trip would be to put it mildly. Yes, I enjoyed the crazy markets and night life of Dakar, the fancy hotels with their swimming pools and French/ Senegalese cuisine, the fascinating drumming and dances of the villagers, a most outrageous local wrestling tournament, and a moving libation ceremony on a Sunday morning in the village sacred space. However, like many unprepared travelers to Senegal, I kept wishing that either Wolof or French would come to me in a flash so I could speak with the local people or at least read the menu. But the one thing that I was totally unprepared for was the ecological disaster that is Senegal—or at least the small area of western Senegal that I saw.

What I observed in a three-hour ride from Dakar to Ndangane was a highly eroded, desert-like landscape that appeared abandoned, overgrazed, and largely without trees except for groves of distinctive baobobs (Adansonia digitaba) in a park preserve and areas of shrubby growth used by local women for cooking fuel and other needs. Winter dust storms (harmattan) reduced the visibility to the point that sun set daily about 3 p.m., not on the Earth's horizon but into a hazy shroud of dust and sand several hundred feet above the horizon. In talking to one of my English-speaking festival-goers who has been coming to Senegal for decades, I learned that this area east of Dakar was once forested, but had been cleared to grow groundnuts or peanuts (Arachis hypogaea) —Senegal's flagship cash crop and the base for the national dish, mafé. Unfortunately, but perhaps inevitably, for the Senegalese, their reliance on a monoculture caught up with them both economically and ecologically and now they find themselves a debtor nation — one of the 18 nations whose national debt will be pardoned as a result of the actions of the latest G8 meeting in Scotland (and the promptings of many, including Live 8 promoters, Bob Geldof and Bono)and with an ecologically impoverished landscape.

When I returned from Senegal, I started looking into what role conservationists and restorationists are and could be playing to assist the Senegalese. Yes, relief of its national debt by the IMF will help Senegal move forward in its efforts to alleviate poverty (68 percent of all Senegalese live on less than \$2 per day) and upgrade the water supply system and sanitary infrastructure. But, additional efforts must be made to correct the environmental damage that exists in a country where the total forest area has declined by 70 percent and the fertility of the soil has largely been lost. I am pleased to report that some fledgling efforts are underway-efforts that, while not ecological restoration in the strictest sense, have the opportunity to heal both the land and its people.

There are two key buzzwords that surround these efforts: "forest land restoration" and "carbon sequestration." Both the World Conservation Union (IUCN) and the World Wildlife Fund are championing the idea of forest land restoration. As defined in IUCN's 2005 publication, Forest Landscape Restoration: Broadening the Vision of West African Forests, "A forest landscape restoration (FLR) approach brings people together to identify and put in place a mix of land-use practices that will help restore the functions of forests across a whole landscape, such as a water catchment. It builds on participatory approaches, bringing together individuals, communities, institutions and local and municipal councils-in short, all stakeholders-to negotiate a common vision for the landscape." Both organizations have pilot projects underway in African countries with this goal and methodology in mind. Whether they end up planting tree species that once existed in the now desertified groundnut fields of Senegal-ana tree (Acacia albida), mbul (Celtis integrifolia), rat (Combritum glutinosem), ditah (Detarium senegalensis), alom (Diospyros mispiliformis), nguer (Guvera senegalinsis), wolo (Termininalia macroptera), and baobob-remains to be seen, but hopefully will be part of these projects.

Similarly, the USGS International Program-Carbon Sequestration in Africa has a pilot program just east of Dakar that aims to reforest a former groundnut area for the dual purposes of carbon sequestration and returning fertility to the soils. Their cooperators include Centre Suivi Ecologique and ISRA in Senegal, USAID, University of Arizona, Colorado State University, Lund University in Sweden, and SACRED AFRICA, which is supported by the Rockefeller Foundation. To this point, efforts by USAID have resulted in 2,470 acres (1,000 ha) of rehabilitated, community-protected areas in rural villages throughout Senegal. While this and the other projects are incredibly small, they represent important first steps that not only improve the environment, but help establish a mind-set in which local people begin to believe that they control their own destiny once again.

May Africans be not only free of debt, but free to choose their future!

Dave Egan 